UDC 614.1/7:612.017

DOI: $10.21668 /$ health.risk/2017.3.13.eng

\title{
EXAMINATION OF SOCIAL AND PSYCHOLOGICAL FACTORS CASUING OCCUPATIONAL STRESS IN LABOR MIGRANTS
}

\author{
M. Khodzhiev, N.F. Izmerov, I.V. Bukhtiyarov \\ Izmerov's Research Institute of Occupational Health, 31 Budennogo avenue, Moscow, 105275, Russian Federation
}

\begin{abstract}
We examined significance which social and psychological factors had in occupational stress evolvement in labor migrants who came to Moscow and Moscow region from Central Asia republics. A separate issue was sexual harassment occurrence which female migrants and Moscow region females faced. Psychological tension, i.e. occupational stress, is a contemporary danger in non-conventional working process (labor migration) and it attracts attention of occupational medicine experts. We determined that there were some social and psychological reasons for occupational stress, such as dissatisfaction with work, low level of integration in working teams, poor living conditions. As per questioning results we revealed single harassment cases (3-5\%) and their number was the same both for female migrants and for females from Moscow region. Neuro-emotional labor intensity category amounted to 3.3-3.2 for millwrights, subways builders, steelmen, and road construction workers; it amounted to 3.1 for other workers; as for female migrants employed in social sphere, their work category was 3.2. The following physiological and psychological peculiarities characterize people with low working adaptation as per criteria of great occupational stress evolvement probability: low attention level, slow visual signals perception, prevalence of high systolic and diastolic blood pressure as a sign of arterial hypertension evolvement. Functional state of labor migrants mostly corresponds to "working strain of 1st and 2nd degree" and "overstrain". Staging in occupational stress evolvement in labor migrants is determined by level of labor neuro-emotional intensity.

It seems vital to provide social and psychological support for labor migrants which can include improvements in occupational training, informing workers on health risks occurring at their working places, training on safe working practices, development of occupational selection culture, organization of rational work and rest regime, providing social support for workers.
\end{abstract}

Key words: labor migrants, social and psychological factors, occupational stress, neuro-emotional labor intensity.

There are data in literature proving that psychosocial factors can cause stress at a workplace, deteriorate workers' health and lead to lower occupational activities efficiency $[3,9]$. Today such issues related to occupational stress as its reasons, peculiarities of its evolvement and its manifestations in various occupational activities are considered vital and worth studying $[6,7,8]$.

Social and economic changes in post-
Soviet states which have been taking place over the last decades have resulted in a complicated and unstable economic situation and it has influenced people's lives considerably as their living standards have dropped dramatically. A lot of them had to leave their homes and start looking for a job outside their countries. This trend can be traced in everyday life worldwide and it is also apparent in Central Asia republics. Employable citizens from former USSR

(C) Khodzhiev M., Izmerov N.F., Bukhtiyarov I.V., 2017

Makhmadamin Khodzhiev - Candidate of Medical Sciences, working for a doctor's degree (e-mail: amin.dok@mail.ru; tel.: +7 (968) 585-12-95).

Nikolay F. Izmerov - Member of the Russian Academy of Sciences, Doctor of Medical Sciences, Professor, Scientific Supervisor.

Igor' V. Bukhtiyarov - Director, Head of Laboratory for Labor Physiology and Preventive Ergonomics, Doctor of Medical Sciences, Professor, a Corresponding Member of the Russia Academy of Sciences (e-mail: niimt@niimt.ru; tel.: +7 (495) 365-02-09). 
republics come to many $\mathrm{RF}$ regions to find a job. Migrants face various stressors, psycho-emotional, psychosocial, and climaticecological factors in their working activities; these factors lead to decrease in body adaptation responses and increase in morbidity and mortality risks. Research performed on labor migrants working in various $\mathrm{RF}$ regions revealed that more than $30 \%$ of employable population lived under constant social and psycho-emotional stress $[13,14,15]$.

As per data given by US National Center for Health Statistics, recently about $25 \%$ of men and women have mentioned apparent emotional stress at their workplace. Literature analysis revealed that certain consequences of strict demands at workplaces, poor work control, and insufficient support provided for workers became apparent in high health risks. Grave neuro-emotional load leads to body functional strain and overstrain which causes 3 times higher risks of primary hypertension evolvement [7]. Most potential stressors at a workplace are identified and described; they are divided into two basic groups, physical and psychological ones [2]. Physical factors which cause stress at a workplace include hazardous and dangerous working conditions: intense noise, high or low temperature, toxic gases or vapors impacts; all such factors are usually accompanied with work areas being overcrowded and isolated.

Economic globalization has resulted in growing competition among RF enterprises and it in its turn leads to stress factor growth among labor migrants who are employed at various enterprises and productions. Number of people suffering from occupational stress is growing most dramatically exactly among labor migrants. Basing on psychophysiological and epidemiological research on stress at a workplace, we detected a correlation between working environment, labor organization, and work nature with pathological physiological changes in adaptation processes evolving in migrants' bodies; these changes can cause risks of various occupational diseases $[3,4,5,10,11]$.

Over the last years a lot of efforts have been made to reveal significance of certain psychosocial features such as labor motivation, labor satisfaction, and sexual harassment among female migrants; scientists have also been trying to find optimal solutions concerning working processes organization, rational workplace organization, and interpersonal relations harmonization. However there are no enough data on studying correlation between social and psychological parameters and labor intensity and physiological features of adaptation processes evolving in migrants' bodies; this very issue is our research subject.

Our research goal was to study significance and peculiarities of psychosocial factors in occupational stress evolvement in labor migrants who had different neuroemotional loads at their workplaces.

Methods. Social and psychological research is usually based on questioning. Questioning is a technique involving use of questionnaires which were developed by WHO experts on the basis of "Country profile" and adapted by us to fit in with our tasks.

Our research included labor intensity characteristics based on job analysis; we took workers with certain hazard category and labor intensity and analyzed their jobs in conformity with P 2.2.2006-05 Guidelines allowing for their working activities structure giving scores to each type of loads [12]. Psychophysiological research was performed with the use of relevant specialized tests including health, activity, and mood assessment; stress; anxiety; rate of visual and auditory information reception via chronological reflexometry; atten- 
tion concentration as per Bourdon test with Landolt rings with the consequent calculation of perceived information volume; short-term memory state as per "numbersspecific memory"; personality structure determination as per MMPI tests and Spielberg test. We applied Leary techniques to determine types of interpersonal relations in teams; these techniques were aimed at workers' psychological compatibility assessment.

We performed physiological assessment of cardiovascular system state as per heart rate, systolic blood pressure, diastolic blood pressure, functional changes index as per Baevskiy, and heart rate variability.

Research results. We performed our research on six professional groups which were selected allowing for neuroemotional, psychosocial, and psychoemotional loads. We assessed significance of psychoemotional and psychosocial factors including labor satisfaction, and cooperation between supervisors and workers. Our examined groups 1 and 2 were made up of labor migrants employed by large construction enterprises in Moscow and Moscow region and working as builders erectors and steelmen; 3 group included subway builders; 4 group was made up of road builders; group 5 was workers employed at a vegetable warehouse; group 6 was made up of workers employed at a vegetable market. A separate group included female migrants employed in social sphere as nurses, child-minders, and housemaids. As we analyzed the structure of the examined groups we detected that basically they were $20.58 \pm 2.74$ years old with working experience equal to $2.25 \pm 0.53$ years. Overall, we examined 219 people. We processed our research results with the use of «Statistika for Windows» applied software and assessed our results validity as per Student's criterion.
Hygienic research results revealed that hazardous substances concentrations in working area air didn't exceed fixed standards for both groups of builders. Assessment of noise at workplaces helped to determine that noise level was 1.5-2 times higher than permissible one only for builders-erectors and builders-steelmen, and subway builders.

We performed functional research of workers' bodies in relatively favorable conditions (August - early September) when temperature, air relative humidity and speed were within optimal and permissible range.

Job analysis allowed us to assign labor of migrants employed by large construction enterprises and Mosmetrostroy (subway construction) to 3.3 labor danger category as per labor intensity related to apparent emotional loads and unfavorable work regime. Builders' labor is an injury-prone activity with high risk for one's life especially when work is performed at a height. Responsibility for other people's safety is determined by necessity to work in a team and to coordinate one's actions with other workers' actions and these workers can in some cases be rather low qualified. Labor intensity for road builders has 3.2 danger category as it involves working under time deficiency (it is necessary to form asphalt before it hardens) and it influences working activities. Neuro-emotional labor intensity is also increased due to constant control related to supervisors' attempts to lower wages. As road carpet compaction is performed manually with the use of a hand vibration tool, it exerts local vibration impacts on workers. Labor intensity of vegetable warehouse workers is caused by this work being highly injury-prone; by workers' ignorance about safe work practices; by necessity to work under time deficiency. All this allows to assign it to 3.2 danger category. Working activities of migrants 
employed at a vegetable market involve substantial interpersonal communication, language barrier overcoming, possibility to meet negative attitudes which local population may have towards migrants. The obtained results prove that labor is intense and has 3.1 danger category. Labor intensity for female migrants employed in social sphere is caused by their working activities peculiarities especially when they have to attend to seriously ill patients, elderly people, or disabled. They often have to work longer hours, without any days off. In some cases emotional strain evolves, or unfavorable interpersonal relations occur. All these job peculiarities which are detected in social sphere activities allow us to assign such work to 3.2 danger category.

Our questioning results were necessary for assessing frequency of psychosocial factors causing stress at a workplace. We separately studied prevalence and reasons of such phenomenon as sexual harassment among labor migrants. Harassment as behavior which violates personal privacy of a worker is rather new for our country; it has been taken from the Anglo-Saxon countries legislation. Such behavior can include jokes, hints, obtrusive molesting, threats, etc. The US legislative system has certain peculiarities due to which a company and not a supervisor (worker) who committed illegal actions acts as a defendant in court cases related to complaints about harassment. Companies usually wish to avoid publicity and reputation losses so they prefer to pay compensations to a victim rather then lose their clients' respect. According to several authors, a concept of harassment and its difference from just simple courtship is determined by social and psychological perceptions which differ from country to country [1]. Questioning results revealed quite rare cases $(3-5 \%)$ of harassment, and their quantity was equal both for female migrants and local people in
Moscow region. About 77\% women never faced harassment.

Prevalence of stress work factors related to apparent neuro-emotional loads turned out not to depend on danger category determined as per labor intensity parameters (Figure 1). Such work requirements as high work speed, and absence of freedom (control over work techniques and quality, its speed, order of operations needed to perform a task) were equal to $20.0 \pm 10.39 \%$ of cases for subway builders (3.3 danger category); $35.0 \pm 8.37 \%$ for vegetable warehouse workers (3.1 danger category); $36.67 \pm 7.97 \%$, for social sphere workers (3.2 category).

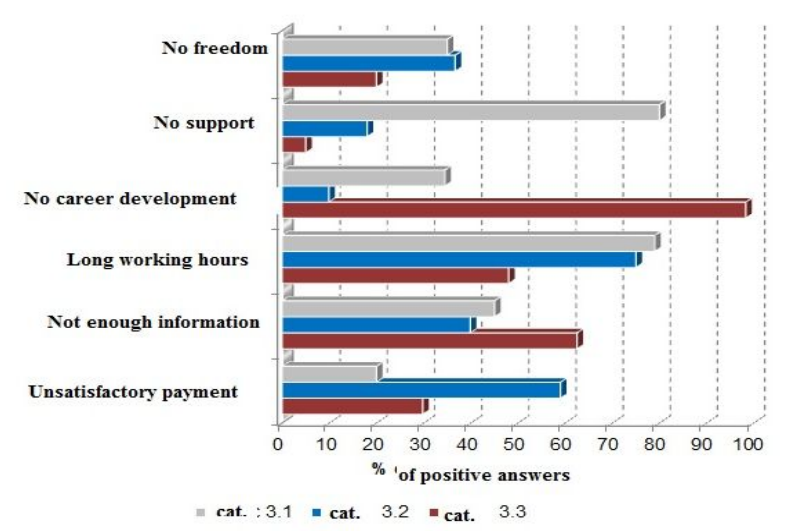

Figure 1. Prevalence of stress factors at a workplace: grew columns show data for vegetable market workers (3.1 category); blue coulmns, social spohere workers (3.2 category); red clumns, builders and subway builders

\section{(3.3 category)}

Influence exerted by adverse factors of work process and working environment is typical for workers employed by large construction enterprises as $50 \%$ of them suffer from it in comparison with $26.6 \%$ of people employed in social sphere. Long working hours as a typical feature of their working life were mentioned by workers from all the occupational groups and it resulted in their poor satisfaction with their labor. Limited social support, bad attitudes of supervisors towards their subordinates who 
was employed with labor contracts, and absence of cooperation, were also mentioned practically by all workers employed by construction enterprises and we can consider it a significant drawback of work process organization in these teams. Poor career possibilities are most apparent in case of builders: $98.3 \pm 3.05 \%$; they were also mentioned by $34.50 \pm 8.98 \%$ of vegetable market workers; by $9.9 \pm 2.035 \%$ of social sphere workers. Discrepancies between groups were statistically significant.

Workers employed by large construction organizations and in subway construction often complained on having very little information on their personal contribution into work results, on their supervisors' plans, on their successes and difficulties, and on other corporate news. Workers employed in social sphere often mentioned they didn't have any material stimuli to work better and that they were unsatisfied with their labor; such results were obtained from $58.49 \pm 8.55 \%$ of workers employed in social sphere, and only from $20.88 \pm 9.05 \%$ of vegetable market workers. Discrepancy in frequency of this psychosocial factor occurrence among workers from the examined occupational groups can be caused by differences in their workloads, namely unsatisfactory working regime with long working hours, night shifts, and absence of any days off which were mentioned by female migrants employed in social sphere.

When being questioned, workers from all occupational groups with labor involving great neuro-emotional loads mentioned necessity of focusing their attention; for example, workers employed by construction enterprises and in subway construction mentioned it in $32.09 \%$ and $39.45 \%$ number of cases correspondingly; necessity to perceive information rapidly and precisely was mentioned by $25.0 \%$ and $20.5 \%$ cor- respondingly; necessity to memorize a great volume of information by listening to, by $12.5 \%$ and $23.1 \%$, and by looking, by $12.5 \%$ and $20.5 \%$; necessity to multitask, by $28,2 \%$ and $43.7 \%$. Work under interferences $(25.0 \%$ positive answers) was most frequently mentioned by vegetable warehouses and markets workers.

As per research results, as labor intensity grew, a share of people complaining on work stress also went up. Stress situations occurred weakly, several times a week in $27.9 \%$ of cases among vegetable market workers; in $38.9 \%$, among social sphere workers; in $54.7 \%$, among builders employed by large construction enterprises and subway builders (Figure 2). In other words, stress situations occurred most frequently at workplaces where labor intensity and danger category was the highest.

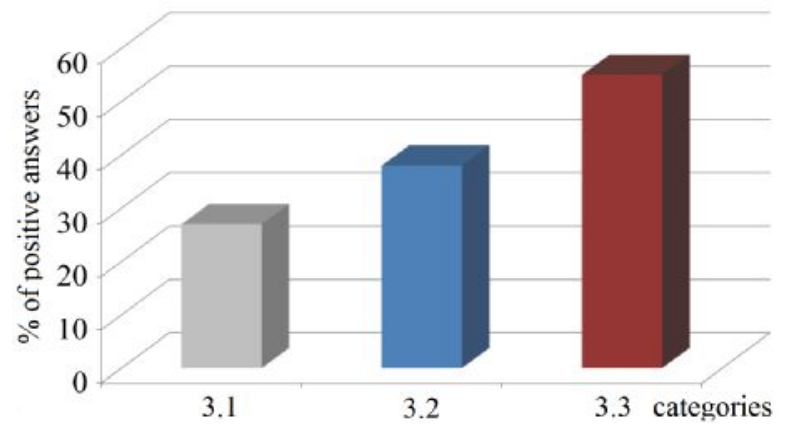

Figure 2. Prevalence of stress factors at a workplace: grew columns show data for vegetable market workers (3.1 category); blue coulmns, social spohere workers (3.2 category); red clumns, builders and subway builders (3.3 category)

When work involves substantial neuro-emotional loads, it leads to poor labor satisfaction. We detected practically the same values before work start in labor migrants employed at construction sites as erectors and steelmen.

Overall, the performed comparative analysis of psychoemotional factors in workers from various occupational groups with different nature, type, and specificity 
of labor, revealed that low labor satisfaction occurred in all teams and it was determined by labor intensity.

We observed changes in labor satisfaction during a shift depending on labor intensity. We detected a fall in labor satisfaction over a shift in subway builders (3.3 category ) by $9.1 \%$ after 8 hours of work and by $10.6 \%(\mathrm{p} \leq 0.05)$ after 12 hours of work; in workers employed by large construction enterprises ( 3.3 category) by $13.2 \%$ ( $\mathrm{p} \leq 0.05$ ) after 12 hours of work. At the same time, we didn't detect any drop in labor satisfaction in workers employed at vegetable market (3.1 category as per labor intensity).

Overall, the performed comparative analysis of psychoemotional factors in workers from various occupational groups with different nature, type, and specificity of labor, revealed that low labor satisfaction occurred in all teams and it was determined by labor intensity. The most apparent decrease in labor satisfaction was detected in labor migrants employed by large construction enterprises and subway builders (3.3 category); smaller decrease was detected in vegetable warehouse workers (3.2 category) and vegetable market workers (3.1 category) in conformity with hazard degree determined as per labor intensity. To confirm this statement: calculated correlation coefficients for correlation between labor satisfaction and labor intensity for the first and second group of workers are equal to $\Gamma=-0.85 ; p \leq 0.05$; for the third group of workers, $\Gamma=-0.64 ; p \leq 0.05$.

Social and psychological factors of group activities efficiency include psychological compatibility of workers and their growing interdependence. Team members' abilities to act together were studied as per Leary tests results. In some cases $(15.0+1.2 \%)$ we observed negative interpersonal relations which caused low interdependence of workers and made activities costs higher. It is especially typical for mi- grants employed at construction sites, subway builders, and female migrants employed in social sphere. Insignificant positive interdependence was detected in workers' teams employed at vegetable warehouses.

Basing on Leary test aimed at interpersonal relations detection we revealed that absence of compatibility or low compatibility of workers played a significant part among factors which determined low labor satisfaction in teams. It is possible to use this test at construction enterprises, subway construction organizations, or in road construction, when a team is being formed. We also detected that labor satisfaction was low in teams where supervisors tended to violate labor contracts, paid wages out of time and not in full volume, and didn't provide working conditions in full conformity with hygienic standards. Labor migrants complained on low social support from their supervisors. At the same time female migrants employed in social sphere mentioned friendly attitudes which their authoritative supervisors had towards them.

The results of changes in psychophysiological parameters and work stress levels in migrants under various emotional labor intensity are given in Table 1.

The obtained parameters values revealed the greatest work stress $(0.69$ arbitrary units) in male migrants employed as erectors by large construction enterprises and as subway builders (3.3 labor intensity category), and it indicated there was increase in amplitude of psychophysiological parameters fluctuations in dynamics during performance of work tasks. Increase in fluctuation range of the examined parameters is caused by strain in regulatory mechanisms which make for body adaptation to new situational conditions. It is determined by 4.0 decrease in attention focus in comparison with 3.1 labor intensity category and by work stress accumulation. We observed lower levels of 
Integral parameter of work strain in male migrants depending on labor intensity category

\begin{tabular}{|c|c|c|c|c|c|}
\hline \multirow[b]{2}{*}{ Physiological parameters } & \multicolumn{5}{|c|}{ Groups of examined workers and labor intensity category } \\
\hline & $\begin{array}{l}\text { Erector and } \\
\text { steelmen } \\
3.3\end{array}$ & $\begin{array}{c}\text { Subway } \\
\text { builders } \\
3.3\end{array}$ & $\begin{array}{c}\text { Road } \\
\text { builders } 3.2\end{array}$ & \begin{tabular}{|c} 
Vegetable \\
warehouse workers \\
3.2
\end{tabular} & $\begin{array}{c}\text { Vegetable } \\
\text { marker workers } \\
3.1\end{array}$ \\
\hline \multirow{2}{*}{$\begin{array}{l}\text { Latent period of simple } \\
\text { visual motor response }\end{array}$} & \multicolumn{5}{|c|}{ Change, $\%$} \\
\hline & 20,1 & 22,0 & 17,4 & 7,5 & 5,5 \\
\hline $\begin{array}{l}\text { Attention focusing as } \\
\text { per volume of perceived } \\
\text { information }\end{array}$ & 17,3 & 18,1 & 15,5 & 9,1 & 3,8 \\
\hline $\begin{array}{l}\text { Index of functional } \\
\text { changes in } \\
\text { system }\end{array}$ & 18,0 & 16,8 & 13,5 & 6,0 & 2,3 \\
\hline \begin{tabular}{|l}
$\begin{array}{l}\text { Maximum muscular } \\
\text { capacity }\end{array}$ \\
\end{tabular} & 26,7 & 25,4 & 26,8 & 13,7 & 5,1 \\
\hline \multicolumn{6}{|c|}{ Integral work strain parameter, arbitrary units } \\
\hline & 0,69 & 0,69 & 0,58 & 0,34 & 0,18 \\
\hline
\end{tabular}

work strain in workers employed as road network repairmen (3.2 category) as well as in vegetable warehouse workers (3.2 labor intensity category) and vegetable market workers (3.1 labor intensity category), 0.58, 0.34 , and 0.18 arbitrary units correspondingly.

Increase in fluctuation range of the examined parameters is caused by strain in regulatory mechanisms which make for body adaptation to new situational conditions. It is determined by 4.0 decrease in attention focus in comparison with 3.1 labor intensity category and by work stress accumulation. We observed lower levels of work stress in workers employed as road network repairmen (3.2 category) as well as in vegetable warehouse workers (3.2 labor intensity category) and vegetable market workers (3.1 labor intensity category), 0.58, 0.34, and 0.18 arbitrary units correspondingly.

Work strain accumulation is accompanied with increase in quantitative values of this strain and leads to evolvement of the second category of it which we observed in case of labor intensity category being 3.2-3.3. And here work strain of the second degree becomes more apparent in prevailing activa- tion processes of vegetative functions. Thus diastolic blood pressure of road network workers grew from $87.3 \pm 1.15$ to $93.80 \pm 1.66$ mmHg during their working shift $(\mathrm{p} \leq 0.05)$. Besides, we revealed a lot of people with borderline arterial hypertension among workers employed by large construction enterprises and among subway builders as their systolic and diastolic blood pressure was within "danger zone" (140/90 - 159/94 $\mathrm{mmHg}$ ) even among relatively young people aged 30-39 and 40-49. All the above stated proves there is decrease in working capacity and unsatisfactory adaptation of migrants who arrived from Central Asia republics to Moscow region conditions.

Primary psychological reasons for occupational stress evolvement are low qualification, workers having insufficient information on hazards and danger (when working at heights), illusions about safety rules violations having no dangerous consequences. Psychological testing revealed that 50$75 \%$ people among labor migrants had increased level of personal anxiety. At the same time situational anxiety wasn't high at the beginning of a work shift and was equal to 20-25 points; by the end of a shift it grew 
to $45-55$ points which were the evidence that anxiety was already high. We didn't detect any gender discrepancies in migrants' psychological state parameters.

In other words, as per psychological testing, we revealed a significant number of people with increased anxiety caused by labor intensity degree and influence exerted by adverse social and psychological factors. Low occupational selection culture is also a very important factor which causes high social risks. This factor is aggravated by poor vocational training of workers.

\section{Conclusions:}

1. Mental stress is a contemporary danger in unconventional labor organization (labor migration); i.e. occupational stress is a problem which attracts a lot of attention of experts in occupational medicine.

2. There are such social and psychological reasons which lead to occupational stress as per specialized analysis data as labor dissatisfaction, harassment, low integration in work teams, and poor living conditions. As per questioning results we revealed quite rare cases (3-5\%) of harassment, and their quantity was equal both for female migrants and local people in Moscow region. About $77 \%$ women never faced harassment.

3. As per job analysis results we determined labor neuro-emotional intensity categories which were 3.2-3.3 for erectors, steelmen, road network workers, and subway builders; other workers had 3.1 category; labor intensity category for female migrants employed in social sphere was 3.2

4. People with poor labor adaptation as per great possibility of occupational stress evolvement have the following physiological and psychological peculiarities: low attention, low rate of visual signals perception, and prevalence of high systolic and diastolic blood pressure, which proves borderline arterial hypertension is starting to evolve.

5. As per physiological research results we detected stages in functional state formation: work strain of I and II category, and overstrain. Stages in occupational stress evolvement in labor migrants are determined by neuro-emotional labor intensity.

6. Social and psychological support for labor migrants includes better vocational training for workers; personnel being better informed about hazards and danger (when working at heights) of occupational factors; training on safety work practices; openness and visualization of consequences (disability etc) which certain diseases can have; information on what causes diseases; occupational selection improvement; organization of rational work and rest regime with fixed working hours; better interaction and psychological compatibility within work teams; provision of workers' social support.

\section{References}

1. Balabanov S.S., Saralieva Z.Kh. Seksual'nye domogatel'stva na rabote v Rossii [Sexual advances on work in Russia]. Vestnik nizhegorodskogo universiteta im. N.I. Lobachevskogo. Seriya: Sotsial'nye nauki, 2010, vol. 17, no. 1, pp. 7-12. (in Russian).

2. Velichkovskii B.T. Sotsial'nyi stress, trudovaya motivatsiya i zdorov'e [Social stress, labor motivation and health]. Byulleten' nauchnogo soveta «Mediko-ekologicheskie problemy zdorov'ya rabotayushchikh», 2005, no. 2, pp. 9-18 (in Russian).

3. Galimov A.R., Kaibyshev V.T. Zdorov'e kak nravstvennaya tsennost' i ego samootsenka vrachami [Health as moral value and its assessment by doctors]. Meditsina truda i promyshlennaya ekologiya, 2005, no. 7, pp. 37-42 (in Russian).

4. Dement'eva S.V. Osobennosti adaptatsii migrantov iz zarubezhnykh stran v gorodakh Rossii po dannym sotsiologicheskikh issledovanii [Adaptation peculiarities of migrants from foreign countries in Russian cities as per sociological research data]. Izvestiya Tomskogo politekhnicheskogo universiteta. Inzhiniring georesursov, 2005, vol. 308, no. 5, pp.195-199. (in Russian). 
5. Dzhafarli N. Sovershenstvovanie mekhanizma sotsial'noi adaptatsii migrantov v Rossii [Developing a social adaptation mechanisms of migrants in Russia]. Sovremennaya psikhologiya: teoriya i praktika: materialy KhVI mezhdunarodnoi nauchno-prakticheskoi konferentsii [Contemporary psychology: theory and practice: Materials of the XVI international theoretical and practical conference]. Moscow, Institut strategicheskikh issledovanii Publ., 2015, pp. 101-105 (in Russian).

6. Izmerov N.F., Lipenetskaya T.D., Matyukhin V.V. Stress na proizvodstve kak vazhnaya sostavlyayushchaya problemy psikhicheskogo zdorov'ya $\mathrm{v}$ obshchestve [Occupational stress as a significant part of psychological health in a society.]. Rossiiskii psikhiatricheskii zhurnal, 2005, no. 2, pp. 12-16 (in Russian).

7. Izmerov N.F., Matyukhin V.V., Yushkova O.I. Stress na rabote [Stress at work]. Bezopasnost' i meditsina truda, 2001, no. 3, pp. 32-37 (in Russian).

8. Izmerov N.F., Tikhonova G.I. Problemy zdorov'ya rabotayushchego naseleniya v Rossii [Health protection problems in Russia's working population]. Problemy prognozirovaniya, 2011, no. 3, pp. 56-70 (in Russian).

9. Kalinina S.A. Rol' psikho-sotsial'nykh faktorov v formirovanii professional'nogo stressa u rabotnikov s razlichnoi stepen'yu napryazhennosti truda [The role of psychological and social factors in establishment of professional stress of workers with different labor intensity]. Vestnik Tverskogo gosudarstvennogo universiteta. Seriya Biologiya i ekologiya, 2007, no. 6, pp. 44-49 (in Russian).

10. Profilaktika stressovogo sostoyaniya rabotnikov pri razlichnykh vidakh professional'noi deyatel'nosti: Metodicheskie rekomendatsii MR 2.2.9.2311-07 [Prevention of stress in workers with various occupations: Methodical Guidelines MP 2.2.9.2311-07]. Moscow, Gosudarstvennym uchrezhdeniem Nauchno-issledovatel'skii institut meditsiny truda RAMN, 2007, 26 p.

11. Poletaev D.V. Adaptatsiya domashnikh rabotnikov-migrantov v Rossii [Adaptation of domestic migrant workers in Russia]. Tezisy dokladov mezhdunarodnoi nauchnoi konferentsii "Chelovek $v$ menyayushchemsya mire. Problemy identichnosti $i$ sotsial'noi adaptatsii $v$ istorii $i$ sovremennosti: metodologiya, metodika i praktiki issledovaniya» [Theses of the reports, International scientific conference "A man in the changing world. Historical and contemporary issues of identity and social adaptation: methodology, methods and research practices»]. Tomsk, Izd-vo Tomskogo universiteta, 2014, pp. 95-96. (in Russian).

12. Rukovodstvo po gigienicheskoi otsenke faktorov rabochei sredy i trudovogo protsessa. Kriterii i klassifikatsiya uslovii truda R 2.2.20006-05 [Guide on hygienic assessment of working environment factors and working process factors. Labor conditions criteria and classification $\mathrm{P}$ 2.2.20006-05]. Moscow, Federal'nyi tsentr gigieny i epidemiologii Rospotrebnadzora, Publ., 2005, 142 p. (in Russian).

13. Simonova N.I. Znachimost' psikhosotsial'nykh faktorov trudovogo protsessa dlya rabotnikov ralichnykh professii v sovremennykh usloviyakh [Importance of psycho-social factors of work process for variable occupations in contemporary conditions]. Meditsina truda i promyshlennaya ekologiya, 2008, no. 6, pp.41-47 (in Russian).

14. Belkic K., Landsberqis P.A. Is job strain a major source of cardiovascular risk. Scand. $J$. Work Environ. Health, 2004, vol. 30, no.2, pp.85-128.

15. Kivimak M., Leonon-Arjas P. Work stress and risk of coronary mortality :prospective cohort study of industrial employees. British. Medical. Journal, 2002, no.3, pp. 857-863.

Khodzhiev M., Izmerov N.F., Bukhtiyarov I.V. Examination of social and psychological factors casuing occupational stress in labor migrants. Health Risk Analysis, 2017, no. 3, pp. 109-117. DOI: 10.21668/health.risk/2017.3.13.eng

Received: 30.11 .2016

Accepted: 20.07.2017

Published: 30.09.2017 